\title{
Diet Quality of patients with chronic Chagas disease in a tertiary hospital: a case-control study
}

\author{
Mariana Pereira de Castilhos ${ }^{[1]}$, Grazielle Vilas Bôas Huguenin ${ }^{[2],[3]}$, Paulo Rogério Melo \\ Rodrigues ${ }^{[4]}$, Emília Matos do Nascimento ${ }^{[5]}$, Basílio de Bragança Pereira ${ }^{[1],[5]}$ \\ and Roberto Coury Pedrosa ${ }^{[1]}$
}

[1]. Hospital Universitario Clementino Fraga Filho, Instituto do Coração Edson Saad, Universidade Federal do Rio de Janeiro, Rio de Janeiro, RJ, Brasil. [2]. Departamento de Nutrição e Dietética, Universidade Federal Fluminense, Niterói, RJ, Brasil.

[3]. Instituto Nacional de Cardiologia, Rio de Janeiro, RJ, Brasil.

[4]. Departamento de Alimentos e Nutrição, Universidade Federal do Mato Grosso, Campo Grande, MT, Brasil.

[5]. Departamento de Bioestatistica a Estatistica Aplicada, Instituto Alberto Luiz Coimbra de Pós-Graduação e Pesquisa de Engenharia, Rio de Janeiro, RJ, Brasil.

\begin{abstract}
Introduction: Nutritional status has been implicated in the modulation of the immune response, possibly augmenting the pathogenesis of Chagas disease $(\mathrm{Cd})$. We evaluated diet quality and nutritional status in adults and elderly patients with chronic $\mathrm{Cd}$ in a tertiary hospital. Methods: A case-control study of Cd patients was conducted, paired for gender, age, and co-morbidities with non-Cd patients. Anthropometric measurements and food frequency questionnaire was used, and diet quality was assessed by the Brazilian Healthy Eating Index-Revised (BHEI-R). The Estimated Average Requirement cut-off points were used to determine the dietary micronutrient adequacy. The Cd group was further grouped according to Los Andes classification. Results: The study participants were $67 \pm 10$ years old, $73.6 \%$ elderly and $63 \%$ female. The prevalence of overweight/obesity and abdominal fat was high in both groups; however, Cd group showed a lower prevalence of obesity and increased risk of disease according to waist circumference classification. There was no difference in BHEI-R score between groups $(\mathrm{p}=0.145)$. The $\mathrm{Cd}$ group had sodium and saturated fat intake above recommendations and low intake of unsaturated fat, vitamin $\mathrm{D}$, E, selenium, magnesium, and dairy products; but higher intake of iron. According to Los Andes classification, group III presented lower intake of whole fruit and dietary fiber. Conclusions: Patients with $\mathrm{Cd}$ were overweight and the quality of their diet was unsatisfactory based on the recommended diet components for age and sex.
\end{abstract}

Keywords: Food consumption. Food habits. Nutritional status. Chagas disease. Brazilian Healthy Eating Index-Revised.

\section{INTRODUCTION}

Chagas disease $(\mathrm{Cd})$ is caused by the parasite Trypanosoma (T.) cruzi, and is the third most important tropical infection in the world. Despite a substantial reduction in the number of T. cruzi infected individuals worldwide, $\mathrm{Cd}$ remains neglected by the media and politicians both nationally and internationally ${ }^{1}$. $\mathrm{Cd}$ is associated with poverty, marginalization, and social vulnerability. It has a major adverse impact on health, quality of life, and social economic development, particularly in lowincome and developing countries ${ }^{2,3}$.

The chronic phase of $\mathrm{Cd}$ has a variety of clinical presentations, usually beginning with the indeterminate form. About $30-40 \%$ of patients will develop lesions 10-30 years after

Corresponding author: Dra. Grazielle Vilas Bôas Huguenin. e-mail: graziellevbhuguenin@gmail.com

Received 9 June 2017

Accepted 14 December 2017 infection on different organs; mainly the heart, the digestive system, or both; leading to the cardiac, digestive, and cardiodigestive forms of the chronic disease, according to former studies (contemporary natural history information is scarce) ${ }^{4,5}$.

Digestive lesions involving the esophagus and colon, or both occur in about $10-15 \%$ of chronically infected patients ${ }^{6}$. These abnormalities usually do not lead to a reduction in life expectancy and patients have a favorable prognosis, low morbidity, the same mortality as the general population, and they are capable of doing any type of activity? ${ }^{7}$. Despite a good prognosis in patients with gastrointestinal dysfunction, epidemiological studies in endemic areas have shown that malnutrition can occur with the progression of the disease ${ }^{8}$. The effect of $\mathrm{Cd}$ in the digestive tract of affected individuals influences the dynamics of swallowing and can lead to changes in nutritional status ${ }^{9,10}$. Adequate nutrition can reduce the risk of colon infection, especially foods with antioxidant compounds ${ }^{11}$. However, nutritional imbalances affect the ability of inflammatory response to protect the host ${ }^{12}$ leading to impairment of immune defenses, such as phagocytic function, 
cell-mediated immunity, and complement system, secretion of antibodies, cytokines production and function. Low levels of body antioxidant nutrients promote cell immunosuppression and may intensify the severity of infection and worsen its evolution ${ }^{13}$.

As such, there is a synergistic interaction between worsening nutritional status which contributes negatively to the development and evolution of infection, and the infection; leading to a worsening nutritional status ${ }^{14}$. Nevertheless, the investigation of $\mathrm{Cd}$ and food intake in human populations are rare. The evaluation of food and nutrients intake in Cd is important for the understanding of infection and for the formulation of strategies for prevention and control of Cd. The purpose of this study was to assess the diet quality and nutritional status in adults and elderly patients with chronic $\mathrm{Cd}$ in a tertiary hospital.

\section{METHODS}

The study was conducted between July 2015 and February 2016 at the Clementino Fraga Filho University Hospital (HUCFF/UFRJ), Rio de Janeiro, Brazil. A case-control approach was used. The Cd group was composed of patients that were out of the endemic area for over 20 years and, with an etiologic diagnosis of $\mathrm{Cd}$ (two different serological tests with the positive reaction to T. cruzi). The selection of patients for the non-infected group was performed from among the outpatients of HUCFF/UFRJ Cardiology Service matched by sex, age, and co-morbidities (hypertension, diabetes mellitus type 2, cerebrovascular accident, and dyslipidemia). Exclusion criteria were unable to accept meals orally, clinical suspicion or diagnosis of liver disease, oncology patients, those with neurological problems, or in the immediate postoperative period (up to 30 days post-surgery).

\section{Ethical considerations}

The study protocol was approved by the Research Ethics Committee of the Clementino Fraga Filho Hospital of the Federal University of Rio de Janeiro (CEP-HUCFF-UFRJ), under the protocol number CAAE 46502615.1.0000.5257, and all patients who agreed to participate signed a consent form.

Both the case and control groups underwent clinical assessment, anthropometric measurement [weight $(\mathrm{kg})$, height $(\mathrm{m})^{15}$ and waist circumference $(\mathrm{cm})^{16}$ ], calculation of body mass index (BMI) $)^{17,18}$, and assessment of food intake and diet quality. Weight, height, and waist circumference were measured three times by a trained nutritionist. The classification of BMI considered a $\mathrm{BMI} \leq 18.5$ as underweight, $\mathrm{BMI} \geq 18.5$ and $<25.0$ as normal, BMI $\geq 25.0$ and $<30$ as overweight, and $\geq 30.0$ as obesity ${ }^{17}$. We used the recommended sex-specific cut-off points for waist circumference: $94 \mathrm{~cm}$ (men) and $80 \mathrm{~cm}$ (women) for increased risk, and $102 \mathrm{~cm}$ (men) and $88 \mathrm{~cm}$ (women) for substantially increased risk. The waist circumference was considered as an indicator of disease risk for type 2 diabetes, hypertension, and CVD using cut off points determined by the World Health Organization (WHO) ${ }^{16}$. The assessment of food intake was carried out by the Food Consumption Frequency Questionnaire (FFQ) ${ }^{19}$ previously validated for an adult population. A trained nutritionist applied the FFQ with a support instrument help (photographic material) ${ }^{20}$. The data was entered once by a researcher and reviewed by a second researcher. The calculation of the diet nutritional value was conducted by analyzing FFQ with Food Processor ${ }^{\circledR}$ program.

The diet quality was assessed by the revised Brazilian Healthy Eating Index (BHEI-R) ${ }^{21}$. This index is composed of 12 items that feature distinct aspects of a healthy diet. They are: Total fruit; Whole fruit; Total vegetables and legumes; Dark green and orange vegetables and legumes; Total grain; Whole grains; Milk; Meats, eggs and legumes; Oils; Saturated fat; Sodium; Solid fat, added sugar and alcohol. Each component was scored at $0,5,10$ or 20 points, with intermediate values calculated in proportion to the foods or nutrients consumed. The maximum score of BHEI-R is 100 points and the higher the score the better the quality of the diet. The item Whole grains of BHEI-R was not used in this study as the FFQ does not distinguish between the types of grains consumed. Instead, ten points were awarded to three servings of grains to $1.000 \mathrm{kcal}$ as a criterion for the highest score in Total grains. Consequently, the BHEI-R in this study consisted of eleven component scores. Information on the energy value, saturated fat, monounsaturated fat (MUFA), polyunsaturated fat (PUFA), trans fat, sodium, and addition of sugar to each food consumed to calculate the BHEI-R were collected from the Brazilian Institute of Geography and Statistics tables ${ }^{22}$; and for other foods, the Food Processor Plus ${ }^{\circledR}$ software (ESHA Research, USA), which consists of a complete food composition table developed by the US Department of Agriculture (United States Department of Agriculture) was used ${ }^{23}$.

The Estimated Average Requirement (EAR) cut-off points according to sex and age were used to determine the dietary micronutrient adequacy ${ }^{24}$.

Participants with $\mathrm{Cd}$ were divided into four groups according to the Los Andes classification: I-A, I-B, II, and III. Group I-A had normal electrocardiogram and echocardiogram - no heart involvement, group I-B included patients at an early stage of cardiac involvement, group II patients were at an advanced stage of cardiac involvement without heart failure (HF), and group III patients were at an advanced stage of cardiac involvement with $\mathrm{HF}^{25}$.

Quantitative variables were expressed as means and standard deviation or $95 \%$ confidence interval (CI) for continuous variables with normal distribution, and percentages for categorical variables. McNemar test was used to compare categorical variables by pairing non- $\mathrm{Cd}$ and $\mathrm{Cd}$ groups. The comparison of the continuous variables was done using paired Student $t$ test. ANOVA test and Bonferroni post-test were used for comparing the Los Andes groups categorized into Cd group, while the Pearson's chi-square test was used for comparison of frequencies among Los Andes groups. Statistical Package for the Social Sciences (SPSS, version 20.0) software was used for analyses and $p$ values $<0.05$ were considered significant.

\section{RESULTS}

Study participants were selected from a cohort of 158 $\mathrm{Cd}$ patients who were actively and regularly followed-up. Fifty-six patients declined participating in this study due to 
an incompatible work day (31), patient's (10), and family (15) decisions; while 21 were excluded because they had one or more exclusion criteria. A final sample of 81 each of infected (with an etiological diagnosis of Cd) and non-infected (controls) from the HUCFF Cardiology Service agreed to participate in the study Table 1 presents the general characteristics of individuals. The mean age was $67 \pm 10$ years (range, 38 to 89 years), $63.0 \%$ of participants were female and $73.6 \%$ were elderly. There was a low prevalence of hypertension $(24.7 \%)$, dyslipidemia $(7.4 \%)$, diabetes $(6.2 \%)$, and stroke $(12.3 \%)$ as documented in medical records. Most of the participants were overweight in both groups, but the prevalence of obesity was lower in Cd group $(p=0.038)$. Waist circumference showed different distribution between $\mathrm{Cd}$ and non-infected groups. The substantially increased risk for diseases was lower in Cd group $(p<0.001)$ (Table 1). There was no difference between the Los Andes groups in the general characteristics, BMI classification, and waist circumference classification.

The mean educational level in $\mathrm{Cd}$ group was $3.4( \pm 3.2)$ years and family's income level was low $(<2$ salary/months). Most of the Cd patients migrated from Bahia in $24.5 \%$ of cases, followed by $22.5 \%, 14.3 \%$, and $12.0 \%$ from Minas Gerais, Paraíba, and Pernambuco, respectively. All the patients had nutrition counselling.

The estimated energy intake was lower in Cd group (BHEI-R average score; $80.8 \pm 5.3$ points) compared to the non-infected group ( $82.1 \pm 6.1$ points $)(p=0.154)$ (Table 2). Regarding BHEI-R components, $\mathrm{Cd}$ group showed a higher consumption of vegetables and sodium, and lower consumption of cereals, milk and dairy products, meat and saturated fats than the noninfected group. The Los Andes groups' analysis showed lower intake of whole fruit by patients at an advanced stage with HF compared to the groups with early cardiac involvement. Less than $50 \%$ of the groups presented with adequate intake of milk and dairy, saturated fat, and sodium, see Figure 1.

The intake of carbohydrates, lipids, and fibers were higher in the Cd group compared to the non-infected group $(\mathrm{p}<0.001)$ (Figure 2). It is noteworthy that there was a lower intake of trans fatty acids by the Cd group $(p<0.0001)$ and low intake of MUFA and PUFA. There was a greater variation in the distribution of the dietary variables in the non-infected group. The dietary intake of vitamins showed lower intake of vitamins A, D, E, magnesium, and selenium in the $\mathrm{Cd}$ group. Although, vitamin E intake was less than the recommendation in both groups, values were even lower in the Cd group. A greater variation in the distribution of vitamins and minerals variables was evident in the non-infected group (Figure 2).

Table 3 shows the intake of macronutrients, dietary fiber, vitamins, and minerals according to Los Andes groups. There was a decrease in the dietary fiber intake of Los Andes groups II and III compared to IA and IB groups.

\section{DISCUSSION}

The present work evaluated the diet quality of $\mathrm{Cd}$ and non-infected groups by BHEI-R, as well as the intake of macronutrients, dietary fiber, and adequacy of micronutrients.
It is the first to date to evaluate food intake of patients with $\mathrm{Cd}$, using a method that measures not only the energy and nutrients intake but also the quality of diet. The food intake profile of patients with $\mathrm{Cd}$ was different from non-infected patients. The Cd group showed a lower intake of energy, vitamins A, D, and $\mathrm{E}$, magnesium, and selenium, lower BHEI-R score for total grain, milk, meats and sodium, and a higher BHEI-R score for saturated fat. Los Andes group III presented a lower intake of whole fruit and dietary fiber. Another important finding of this study was the high prevalence of overweight and abdominal fat in both groups, although $\mathrm{Cd}$ group showed a lower prevalence of obesity and increased risk of disease for type 2 diabetes, hypertension, and CVD according to waist circumference classification.

We observed the cohort effect when considering the mean age of patients. Similarly, Viotti et $\mathrm{al}^{26}$ found $\mathrm{Cd}$ patients to be around 66 years, similar to our study. In studies carried out in the $1960 \mathrm{~s}$ and $1970 \mathrm{~s}^{27-29}$ the mean age of patients with $\mathrm{Cd}$ was $\leq 25$ years. The progressive increase in the mean age of patients over the years is referred to as the cohort effect ${ }^{30}$. In turn, studies from the 1990s tend to include adults $\geq 40$ years and older (adult-elderly). Knowledge of the natural history of $\mathrm{Cd}$ anticipates impairment of organs with increasing age, due to the slowly progressing nature of $\mathrm{Cd}$. However, in this study and in other urban series ${ }^{26,31}$, progression may already have occurred in study participants by virtue of their age and may explain the fewer co-morbidities reported by medical records in the $\mathrm{Cd}$ group.

The digestive form of $\mathrm{Cd}$ occurs in about $10-15 \%$ of chronically infected patients. Contemporary natural history information is scarce in relation to the digestive form. The HUCFF at Federal University of Rio de Janeiro/Brazil is a reference center dedicated to treatment and research of esophagopathy and colopathy in $\mathrm{Cd}$, hence, a high esophagus and colon diseases are expected. The $\mathrm{Cd}$ and the cohort at HUCFF include patients with early involvement of the esophagus/colon according to Cabral et al. ${ }^{32}$ However, this study was limited in that it was not possible to evaluate esophagus/colon disease in all patients in this study, because the most accurate diagnostic test uses the application of radioisotope and is not performed routinely. Digestive disease can affect the BMI and patients with digestive form of $\mathrm{Cd}$ receive nutritional counselling that can affect their diet quality.

This study showed that $\mathrm{Cd}$ patients had increased risk of disease considering the high BMI and high waist circumference. Similar findings were shown by Geraix ${ }^{33}$ in 66 adult patients with positive serology for $\mathrm{Cd}$, showing a high frequency of obesity (62\%), as measured by BMI and increased risk of metabolic disease (55\%), assessed by waist circumference. It is important to note that the cardiac form is the most severe and frequent manifestation of chronic $\mathrm{Cd}^{34}$, and the presence of obesity significantly increases morbidity and mortality from other diseases, such as hypertension, dyslipidemia, coronary artery disease, diseases biliary tract, osteoarticular diseases, type 2 diabetes mellitus, and some cancers ${ }^{29,34,35}$. Also, it is known that obesity is associated with subclinical inflammation, 


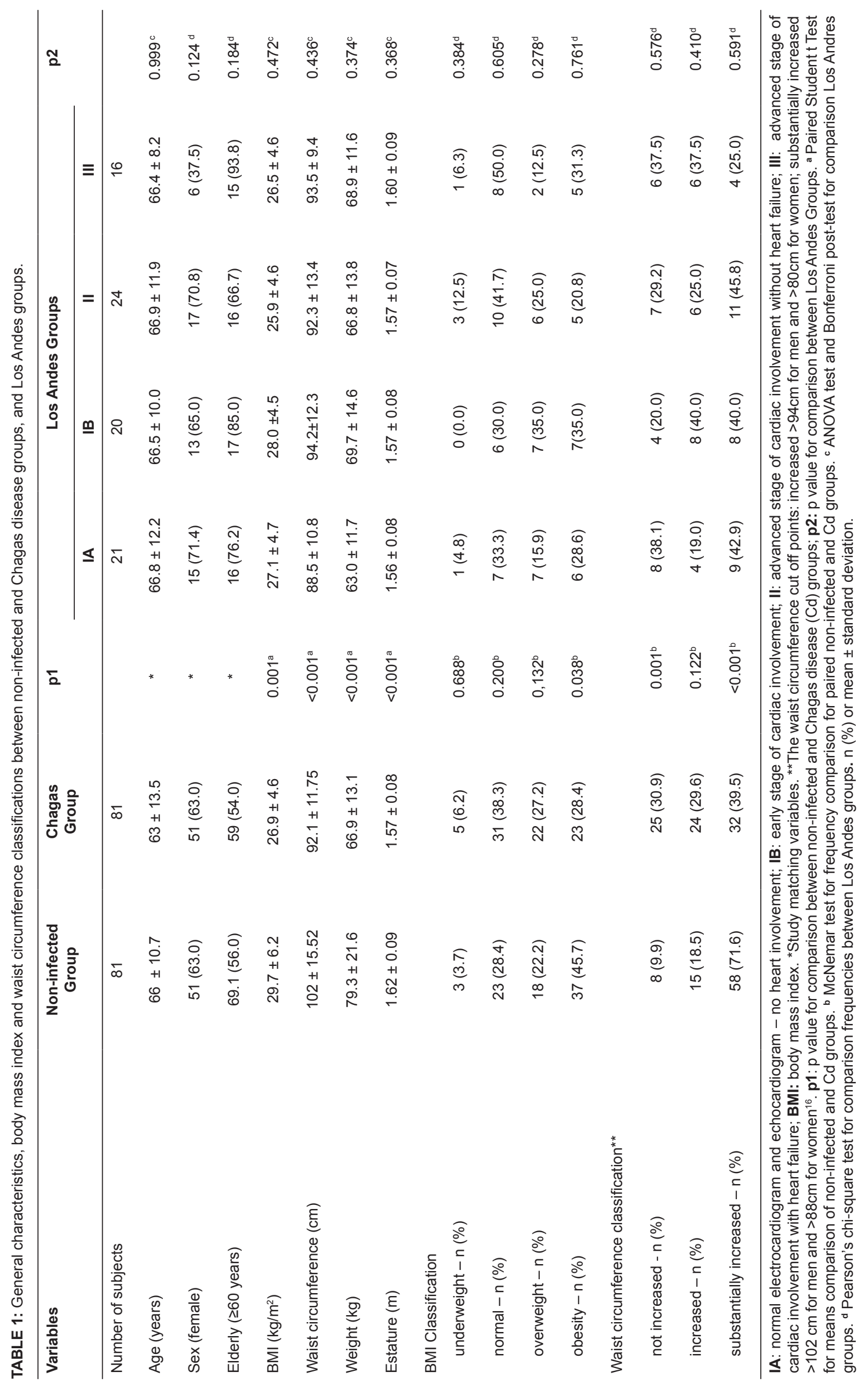




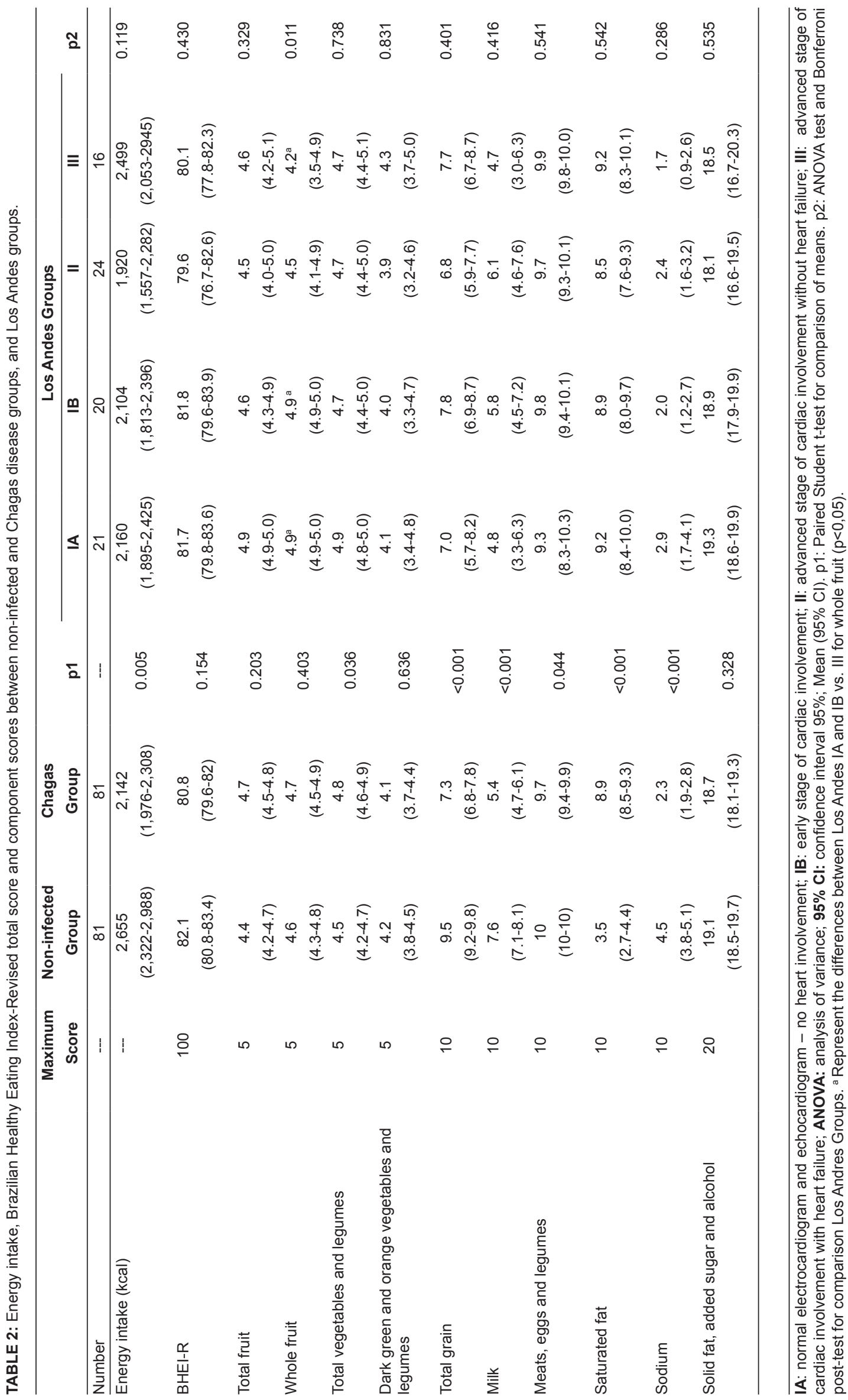




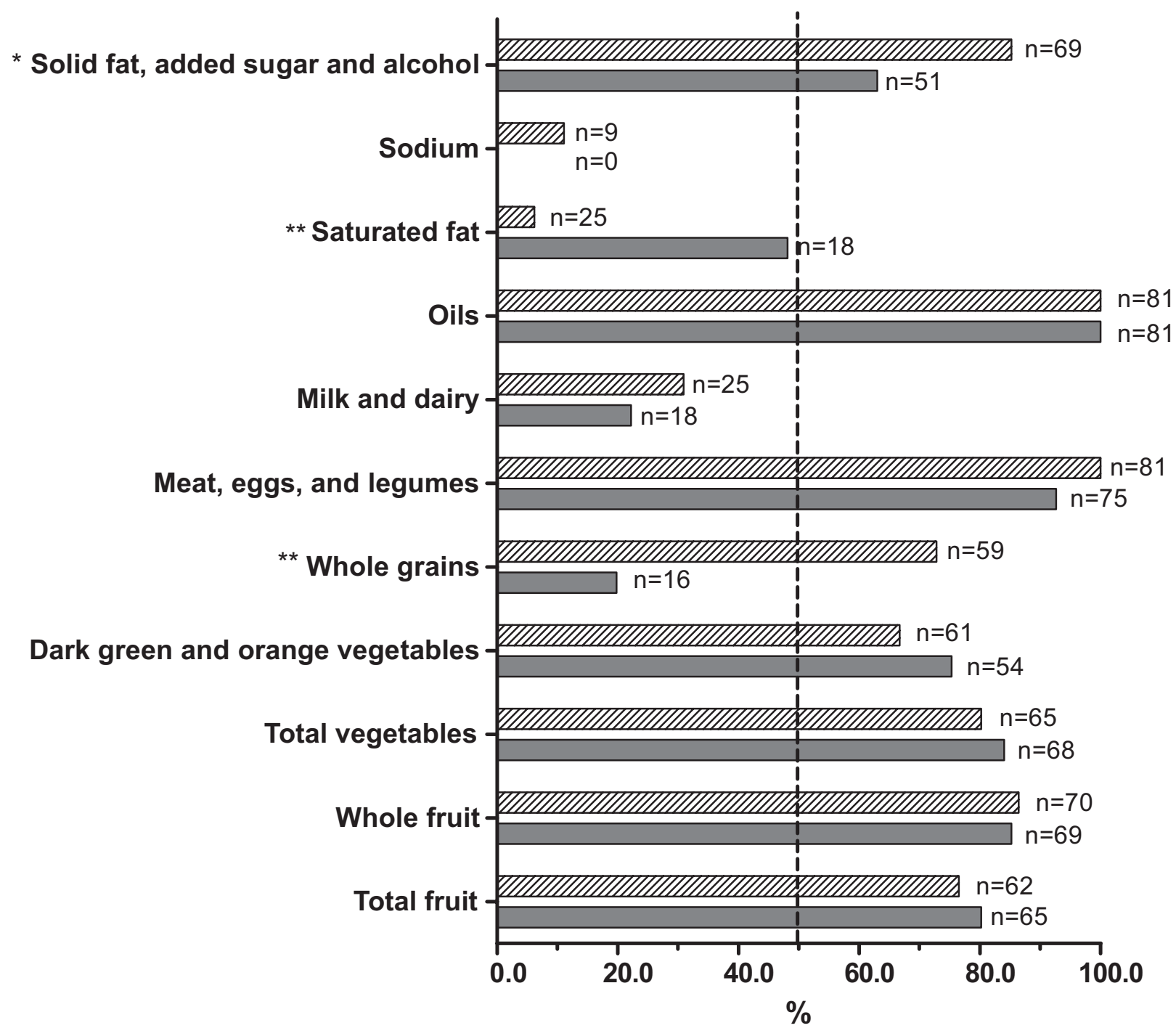

WIIA Non-infected group

Chagas group

FIGURE 1 - Relative frequency of individuals who achieved the recommended intake in the different components of the BHEI-R. The McNemar test was performed. BHEI-R: Brazilian Healthy Eating Index-Revised. ${ }^{*} p<0.001$ and ${ }^{* *} p<0.01$.

promotes the secretion of cytokines, leads to the initiation of pro-inflammatory events, and oxidative stress ${ }^{36}$. As $\mathrm{Cd}$ is an inflammatory disease, obesity could aggravate the evolution of the disease. According to some studies, adipocytes are an important target for infection by T. cruzi, functioning as host cell and reservoir in chronic $\mathrm{Cd}^{37}$. The $\mathrm{Cd}$ group presented a high prevalence of overweight/obesity, and it could worsen the course of the disease in these patients.

In the $\mathrm{Cd}$ group, it was possible to observe a smaller variation of consumption of BHEI-R components, this fact was a constant in the study. Possibly, the lower variation in food consumption in patients with $\mathrm{Cd}$ reflected the complications of these patients, such as dysphagia, leading to the impairment of the quality and amount of food. Other complications arising in these patients are impairment of the gastrointestinal tract, which affects food motility, and permanent reflux of partially digested food material. According to Torres ${ }^{38} 77 \%$ of Cd patients in their study reported discomfort during feeding. Possibly, this may explain why the $\mathrm{Cd}$ group obtained a better score for the fruit and vegetable groups, and a lower score for the cereals group because of adaptation by patients in their diet, resulting from difficulty in swallowing food, especially solid foods.

The results showed that the total score of BHEI-R did not differ among the groups. However, when evaluating the food 


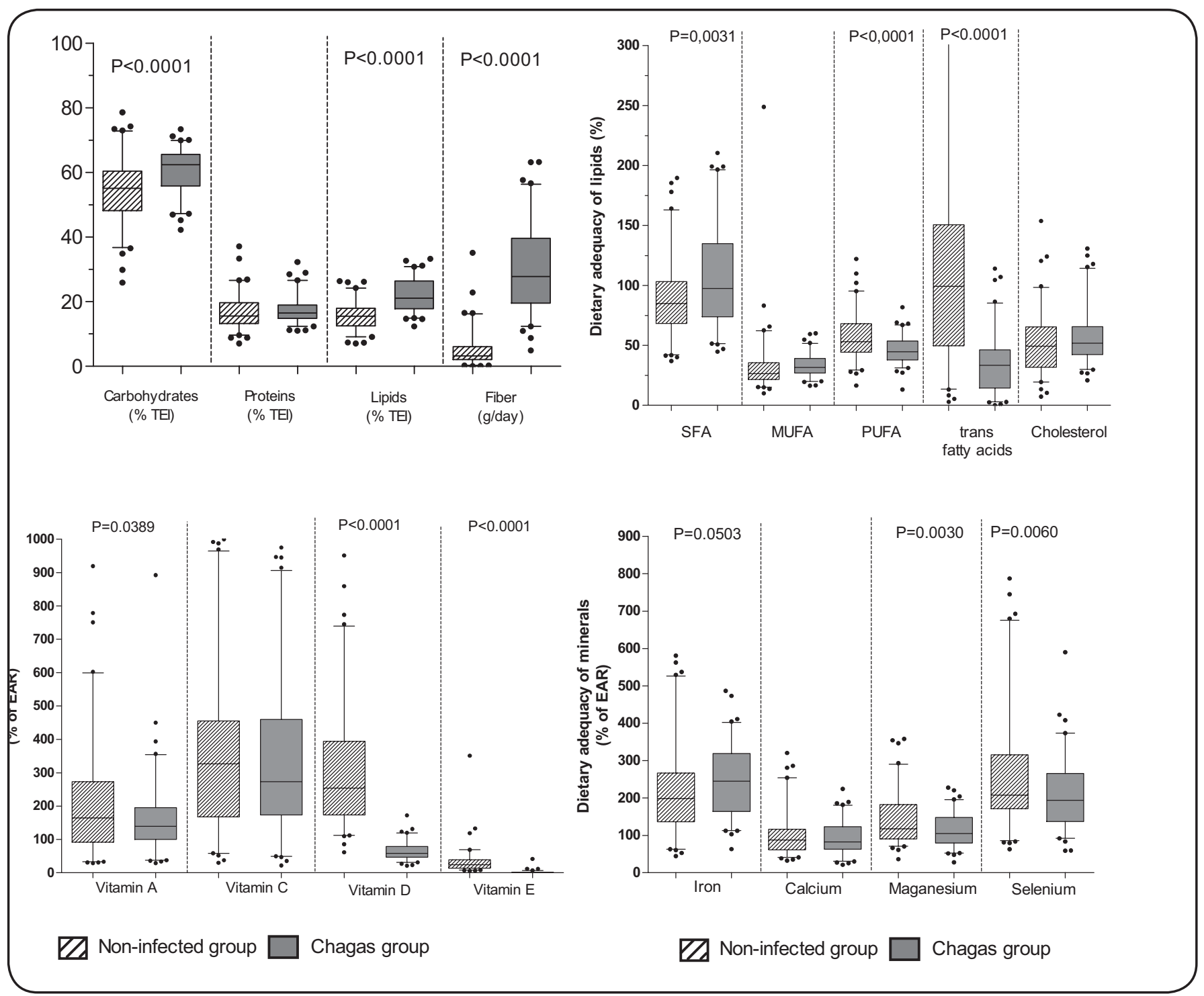

FIGURE 2 - Box plots representing macronutrients and micronutrients intake. The values in the boxes represent the median and interquartile intervals, the whiskers represent the $5^{\text {th }}$ and $95^{\text {th }}$ percentiles, and the outliers are plotted as individual values. Paired Student $t$ test was performed.

components, significant differences were observed among the groups. As there was no study that evaluated dietary intake in Cd patients, we compared our findings to general studies that evaluated dietary intake and diet quality by BHEI-R. Since most patients in this study were older, a population-based study of 1,509 elderly $^{39}$ aimed at assessing quality diet of the elderly according to sociodemographic variables, behaviors related to health and morbidities was considered. Assumpção et al. ${ }^{39}$ showed similar population characteristics that were found in the present study, a higher proportion of women $(57 \%)$ and elderly (53.8\%) and an average of BHEI-R score 62.4. In the Assumpção's study, a different method of dietary assessment, using a 24-hour recall, was used, while in this study, FFQ was used. According to the literature, other BHEI scores tend to be overestimated when the FFQ is used ${ }^{40}$. Also, Cd patients have clinical follow-up of many years, and are likely to have already received nutritional advise. The results of this study indicate worse scores on cereals, milk and dairy, meats and saturated fat in the $\mathrm{Cd}$ group. The consumption of fruits and vegetables in their usual diet can lead to lower cereal intake.

The percentage of macronutrients intake showed that $\mathrm{Cd}$ group presented higher lipid consumption in diet, and the profile of this consumption was high in saturated fat, and lower in PUFA. Considering a population with low socioeconomic level, this profile of fat consumption could be related to the consumption of products rich in saturated fat and at a more affordable price, such as sausages, ultra-processed biscuits, and cakes and lower consumption of foods rich in unsaturated fat, such as oilseeds, vegetable and olive oils which are more expensive. Considering the cardiovascular impairment of these patients, the lipid profile is a concern for the dietary advise. The deleterious role of saturated fatty acid intake in glycolipid metabolism is well-established. Metabolic and epidemiological studies ${ }^{41}$ have shown that saturated fatty acid raises the plasma 
TABLE 3: Intake of macronutrients, dietary fiber, vitamins and minerals according to Los Andes groups.

\begin{tabular}{|c|c|c|c|c|c|}
\hline & \multicolumn{4}{|c|}{ Los Andes Groups } & \multirow{2}{*}{$\mathbf{p}$} \\
\hline & IA & IB & II & III & \\
\hline Total energy (kcal/day) & $\begin{array}{c}2,160 \\
(1,895-2,425)\end{array}$ & $\begin{array}{c}2,104 \\
(1,813-2,396)\end{array}$ & $\begin{array}{c}1,920 \\
(1,557-2,282)\end{array}$ & $\begin{array}{c}2,499 \\
(2,053-2,945)\end{array}$ & 0.119 \\
\hline Carbohydrate (\% TEI) & $\begin{array}{c}61.3 \\
(58.9-63.6)\end{array}$ & $\begin{array}{c}61.3 \\
(58.4-64.3)\end{array}$ & $\begin{array}{c}60.5 \\
(57.3-63.6\end{array}$ & $\begin{array}{c}59.1 \\
(54.6-63.6)\end{array}$ & 0.751 \\
\hline Protein ( $\%$ TEI) & $\begin{array}{c}17.6 \\
(15.8-19.4)\end{array}$ & $\begin{array}{c}17.1 \\
(15.2-18.9)\end{array}$ & $\begin{array}{c}16.5 \\
(15.0-18.1)\end{array}$ & $\begin{array}{c}18.5 \\
(16.2-20.7)\end{array}$ & 0.472 \\
\hline Lipids (\% TEI) & $\begin{array}{c}21.0 \\
(19.0-23.0)\end{array}$ & $\begin{array}{c}21.5 \\
(19.4-23.6)\end{array}$ & $\begin{array}{c}22.9 \\
(20.4-25.4)\end{array}$ & $\begin{array}{c}22.3 \\
(19.4-25.1)\end{array}$ & 0.618 \\
\hline Saturated fatty acid (\% TEI) & $\begin{array}{c}6.8 \\
(5.3-8.3)\end{array}$ & $\begin{array}{c}8.0 \\
(6.7-9.3)\end{array}$ & $\begin{array}{c}8.1 \\
(6.7-9.4)\end{array}$ & $\begin{array}{c}6.8 \\
(5.6-7.9)\end{array}$ & 0.288 \\
\hline Monounsaturated fatty acid (\% TEI) & $\begin{array}{c}6.0 \\
(5.4-6.7)\end{array}$ & $\begin{array}{c}7.2 \\
(6.2-8.2)\end{array}$ & $\begin{array}{c}6.7 \\
(5.9-7.5)\end{array}$ & $\begin{array}{c}6.7 \\
(5.6-7.8)\end{array}$ & 0.247 \\
\hline Polyunsaturated fatty acid (\% TEI) & $\begin{array}{c}4.3 \\
(3.8-4.8)\end{array}$ & $\begin{array}{c}4.8 \\
(4.3-5.3)\end{array}$ & $\begin{array}{c}4.6 \\
(4.1-5.1)\end{array}$ & $\begin{array}{c}4.6 \\
(4.1-5.1)\end{array}$ & 0.587 \\
\hline Trans fatty acid (\% TEI) & $\begin{array}{c}0.25 \\
(0.18-0.32)\end{array}$ & $\begin{array}{c}0.33 \\
(0.21-0.45)\end{array}$ & $\begin{array}{c}0.34 \\
(0.24-0.43)\end{array}$ & $\begin{array}{c}0.31 \\
(0.17-0.44)\end{array}$ & 0.601 \\
\hline Cholesterol (mg/day) & $\begin{array}{c}268.4 \\
(199.6-337.2)\end{array}$ & $\begin{array}{c}255.5 \\
(218.6-292.3)\end{array}$ & $\begin{array}{c}270.1 \\
(191.2-349.0)\end{array}$ & $\begin{array}{c}273.3 \\
(215.5-331.0)\end{array}$ & 0.981 \\
\hline Dietary fiber (g/day) & $\begin{array}{c}34.3^{\mathrm{a}} \\
(27.5-41.2)\end{array}$ & $\begin{array}{c}26.6^{\mathrm{b}} \\
(21.6-31.6)\end{array}$ & $\begin{array}{c}8.6^{a . b} \\
(7.2-10.1)\end{array}$ & $\begin{array}{c}1.4^{\mathrm{a} . \mathrm{b}} \\
(1.1-1.7)\end{array}$ & $<0.0001$ \\
\hline Vitamin A (\% EAR) & $\begin{array}{c}183.6 \\
(136.6-230.6)\end{array}$ & $\begin{array}{c}147.4 \\
(120.0-174.8)\end{array}$ & $\begin{array}{c}166.6 \\
(97.6-235.5)\end{array}$ & $\begin{array}{c}136.1 \\
(83.6-188.5)\end{array}$ & 0.618 \\
\hline Vitamin C (\% EAR) & $\begin{array}{c}406.3 \\
(296.2-516.4)\end{array}$ & $\begin{array}{c}303.4 \\
(216.8-390.1)\end{array}$ & $\begin{array}{c}295.6 \\
(191.6-399.7)\end{array}$ & $\begin{array}{c}307.9 \\
(190.6-425.1)\end{array}$ & 0.345 \\
\hline Vitamin D (\% EAR) & $\begin{array}{c}44.5 \\
(39.3-49.8)\end{array}$ & $\begin{array}{c}45.3 \\
(37.9-52.8)\end{array}$ & $\begin{array}{c}39.0 \\
(29.7-48.4)\end{array}$ & $\begin{array}{c}45.0 \\
(33.4-56.6)\end{array}$ & 0.621 \\
\hline Vitamin E (\% EAR) & $\begin{array}{c}4.0 \\
(-2.0-10.1)\end{array}$ & $\begin{array}{c}2.8 \\
(1.3-4.3)\end{array}$ & $\begin{array}{c}1.6 \\
(0.14-3.05)\end{array}$ & $\begin{array}{c}2.2 \\
(-0.10-4.57)\end{array}$ & 0.740 \\
\hline Calcium (\% EAR) & $\begin{array}{c}99.93 \\
(81.6-118.2)\end{array}$ & $\begin{array}{c}100.4 \\
(76.8-123.9)\end{array}$ & $\begin{array}{c}93.01 \\
(73.1-112.9)\end{array}$ & $\begin{array}{c}79.19 \\
(62.2-96.2)\end{array}$ & 0.450 \\
\hline Iron (\% EAR) & $\begin{array}{c}267,7 \\
(227,2-308,2)\end{array}$ & $\begin{array}{c}236,5 \\
(195,9-277,2)\end{array}$ & $\begin{array}{c}239,7 \\
(197,2-282,1)\end{array}$ & $\begin{array}{c}270,7 \\
(215,1-326,3)\end{array}$ & 0.551 \\
\hline Magnesium (\% EAR) & $\begin{array}{c}124,4 \\
(104,0-144,8)\end{array}$ & $\begin{array}{c}112,1 \\
(93,4-130,9)\end{array}$ & $\begin{array}{c}105,1 \\
(86,5-123,6)\end{array}$ & $\begin{array}{c}121,8 \\
(93,3-150,4)\end{array}$ & 0.476 \\
\hline Selenium (\% EAR) & $\begin{array}{c}238,5 \\
(198,7-278,2)\end{array}$ & $\begin{array}{c}197,6 \\
(144,4-250,9)\end{array}$ & $\begin{array}{c}186,9 \\
(149,9-224,0)\end{array}$ & $\begin{array}{c}206,8 \\
(164,9-248,7)\end{array}$ & 0.302 \\
\hline
\end{tabular}

Data are expressed in mean [95\% confidence interval (CI 95\%)]. IA: normal electrocardiogram and echocardiogram - no heart involvement; IB: early stage of cardiac involvement; II: advanced stage of cardiac involvement without heart failure; III: advanced stage of cardiac involvement with heart failure; TEI: total energy intake; EAR: estimated average requirement. p: ANOVA test and Bonferroni post-test for comparison Los Andres Groups.

concentration of total and low-density lipoprotein cholesterol (LDL-C), compared to PUFA. Margioris ${ }^{42}$ reviewed the impact of consumption of saturated fats on inflammatory profile and showed that saturated fats increased inflammatory markers in the postprandial period, which does not occur with MUFA and PUFA. Fnu Nagajyoth ${ }^{43}$ analyzed in vitro, the effect of the high-fat diet in the regulation of acute myocarditis caused by T. cruzi, and the effect on lipid metabolism in adipose tissue and heart. They showed that persistence of the inflammatory infiltrate contributes to the chronic pathology in the heart ${ }^{43}$.

Dietary fiber intake was apparently satisfactory in Cd group, but there was a lower intake in the advanced stage of cardiac involvement. This could be associated with the lower intake of whole fruit.

It is important to point out that parasitic infection and micronutrient deficiencies coexist in developed countries, and usually have complex interactions that promote deleterious 
clinical effects, and which are mutually reinforcing ${ }^{44}$. Consumption below the EAR for vitamin D, E may be related to lower consumption of fatty fish and oilseeds by the $\mathrm{Cd}$ group. In 2007, Maçao et $\mathrm{al}^{45}$ carried out a study where patients used antioxidant therapy and showed that this intervention was able to neutralize the progressive oxidative stress associated with the Cd. Pitz ${ }^{46}$ has shown that low levels of vitamin D are associated with a higher prevalence of myocardial dysfunction and death due to cardiovascular failure and sudden death.

The average consumption of the minerals magnesium, iron, and selenium were adequate. However, when comparing the consumption among the groups, the $\mathrm{Cd}$ group presented lower consumption of magnesium and selenium. The fact that this group had lower consumption of grains, milk, and dairy probably explains the lower consumption of these minerals. The low consumption of selenium has been indicated as a contributory factor in some cases of congestive cardiomyopathy and increased cardiovascular complications, including myocardial infarction ${ }^{47}$. Rivera ${ }^{48}$ confirmed the hypothesis that cardiomyopathy in $\mathrm{Cd}$ is associated with a decrease of selenium, and this association arose from the result of low concentrations of selenium in cases of more severe $\mathrm{Cd}$. Additionally, calcium intake was below the recommendation in both groups. Observational studies confirm that the diet rich in potassium, magnesium, and calcium is associated with lower incidence and mortality due to cardiovascular diseases ${ }^{49}$ making calcium one of the most important minerals for individuals with cardiovascular complications like Cd patients.

This study had limitations, including the possibility of under- and over-reported energy intake assessed by FFQ that may have under or overestimated the food consumption data analyzed, but the use of simpler criteria $(<500$ and $>3,500 \mathrm{kcal} /$ day) is still controversial in the literature. The BHEI-R results were already adjusted for energy intake because BHEI-R method attributes the scores considering the servings consumed for 1000 kcal. Andrade et al. ${ }^{50}$ evaluated the validity of the construct, and observed that BHEI-R was reliable and structurally valid to estimate the quality of the Brazilians' diet. In addition, the authors point out that an additional advantage in working with an index such as BHEI-R is due to the fact that its calculation is based on energy density (portion/1,000kcal), which attenuates the effect of total energy intake on the index. Another limitation is that FFQ does not address questions about the intake of whole grains, so this component was absent in the analysis. However, the scores of whole grains were attributed to total grains. Despite its limitations, FFQ can estimate the usual food consumption over a period of time, is a recommended method for epidemiological studies, due to its easy applicability and low $\cos ^{51}$.

In conclusion, this study showed that the patients with $\mathrm{Cd}$ were overweight and the quality of the diet was unsatisfactory, as regards the recommendations of the diet components for age and sex. The diet appears to be compatible with an inflammatory diet (high intake of sodium and saturated fat, and low intake of PUFA, vitamins D and E).

\section{Conflict of interest}

The authors declare that they have no competing interests.

\section{Financial support}

Scholarship of Conselho Nacional de Desenvolvimento Cientifico e Tecnológico $(\mathrm{CNPq})$

\section{REFERENCES}

1. World Health Organization (WHO). Working to overcome the global impact of neglected tropical diseases. First WHO report on neglected tropical diseases [Internet]. WHO; 2010. 184p Available from: http://apps.who.int/iris/bitstream/10665/44440/1/9789241564090_ eng.pdf

2. Hotez PJ, Molyneux DH, Fenwick A, Ottesen E, Ehrlich Sachs $\mathrm{S}$, Sachs JD. Incorporating a rapid-impact package for neglected tropical diseases with programs for HIV/AIDS, tuberculosis and malaria. PLoS Med. 2006;3(5):e-102.

3. Coura JR. Chagas' disease: what is known and what's needed - A background article. Mem Inst Oswaldo Cruz. 2007;102 (Suppl 1):113-22.

4. Andrade JP, Marin-Neto JA, Paola AAV de, Vilas-Boas F, Oliveira GMM, Bacal F, et al. I Latin American guidelines for the diagnosis and treatment of Chagas' heart disease: executive summary. Arq Bras Cardiol. 2011;96(6):434-42.

5. Rassi AJr., Rassi A, Marin-Neto JA. Chagas disease. Lancet. 2010;375:1388-402.

6. Chaimowicz F. A saúde dos idosos brasileiros às vésperas do século XXI: problemas, projeções e alternativas. Rev Saúde Pública. 1997;31:184-200.

7. RochaMO, Correia PC, Barros MV, Torres RM, Ribeiro AL, Teixeira MM. Cardiovascular function in elderly patients with chronic chagasic cardiopathy. Rev Soc Bras Med Trop. 2003;36(5):545-50.

8. Oliveira FA, Teixeira VP, Lino RSJr, Vinaud MC, Reis MA. Macroscopic aspects of chronic Chagas heart disease in aging. Arq Bras Cardiol. 2007;88(4):486-90.

9. Yamada EK, Siqueira KO, Xerez DK, Koch HA, Costa MMB. A influência das fases oral e faríngea na dinâmica da deglutição. Arquivos de Gastroenterologia. 2004;41(1):18-23.

10. Santos C, Cassiani RA, Dantas RO. Avaliação clínica da deglutição na doença de Chagas. Rev. soc. bras. fonoaudiol. 2011;16(2 ):215-20.

11. Jelicks LA, Souza AP, Araújo-jorge TC, Tanowitz HB. Would selenium supplementation aid in therapy for Chagas Disease? Trends in Parasitology. 2011;27(3):102-5.

12. Capík I. Periodontal health vs. various preventive means in toy dog breeds. Acta Veterinária Brunensis, Košice. 2010;79(4):637-45.

13. Moynihan P, Petersen PE. Diet, nutrition and the prevention of dental diseases. Public Health Nutricion. 2006;7(1A):201-26.

14. Brunetto MA, Gomes MOS, Jeremias JT, Oliveira LD, Carciofi AC. Imunonutrição: o papel da dieta no restabelecimento das defesas naturais. Acta Scientiae Veterinariae. 2007;35(2):230S-32.

15. BRASIL. Ministério da Saúde. Orientações para coleta e análise de dados antropométricos em serviços de saúde: norma técnica do sistema de Vigilância Alimentar e Nutricional - SISVAN. Brasília: Ministério da Saúde, 2011. (Série G. Estatística e Informação em Saúde).

16. World Health Organization. Waist circumference and waisthip ratio: report of a WHO expert consultation. Geneve: 
WHO. 2008. Available from: http://apps.who.int/iris/ bitstream/10665/44583/1/9789241501491_eng.pdf

17. World Health Organization. Obesity: preventing and managing the global epidemic: report of a WHO Consultation. Geneve: WHO. 2000.

18. Organização Pan-Americana. XXXVI Reunión del Comitê Asesor de investigaciones em Salud - Encuestra Multicêntrica - Salud Beinestar y Envejecimeiento (SABE) em América Latina e el Caribe - Informe preliminar. OPAS. 2002.

19. Sichieri R, Everhart J E. Validity of a Brazilian Food Frequency Questionnaire against dietary recalls and estimated energy intake. Nutrition Research, 1998;18(10):16494-59.

20. Zabotto CB, Vianna RPT, Gil MF. Registro fotográfico para inquéritos dietéticos: utensílios e porções. Rio de Janeiro/ Goiânia; 1996.1-74.

21. Previdelli AN, Andrade SC, Pires MM, Ferreira SRG, Fisberg RM, Marchioni DM. Índice de qualidade da dieta revisado para população brasileira. Rev Saúde Pública. 2011;45(4):794-8.

22. Instituto Brasileiro de Geografia e Estatística (IBGE). Pesquisa de Orçamentos Familiares 2008/2009: Tabelas de Composição Nutricional dos Alimentos Consumidos no Brasil. Rio de Janeiro: IBGE; 2011.

23. United States Departament of Agriculture, Agricultural Research Service (USDA). Department of Agriculture, Agricultural Research Service. USDA Nutrient Database for Standard Reference, 2011.

24. Food and Nutrition Board, Institute of Medicine, National Academies of Sciences. Dietary Reference Intakes: EAR, RDA, AI, Acceptable Macronutrient Distribution Ranges, and UL [internet]. Washington, DC: National Academy of Sciences; 2017. [updated 2017 Jan 28; cited 2017 Dec 14].Available from: http:// www.nationalacademies.org/hmd/ /media/Files/Activity\%20Files/ Nutrition/DRI-Tables/5Summary\%20TableTables\%2014.pdf?la=en

25. Bern C, Montgomery SP, Herwaldt BL, Rassi Jr A, Marin-Neto JA, Dantas RO, et al. Evaluation and treatment of chagas disease in the United States: a systematic review. JAMA, v. 298, n. 18, p. 21712181, 2007.

26. Viotti R, Vigliano C, Armenti H, Segura E. Treatment of chronic Chagas' disease with benznidazole: Clinical and serologic evolution of patients with long-term follow-up. Am Heart J. 1994;127(1):151-62.

27. Puigbó JJ, Rhode JR, Barrios H, Yepez C. Cuatro años de estudio longitudinal de una comunidad rural com endemicidad chagasica. Boletín de la Oficina Sanitaria Panamericana. 1969;66:112-20.

28. Moleiro F, Pifano F, Anselmi A, Ruesta V. La dinámica epidemiológica de La enfermedad de Chagas em el Valle de los Naranjos, Estado Carabobo, Venezuela: II, La infección chagásica em La población rural del área. Arch Venez Med Trop Parasit Méd. 1973;5:31-45.

29. Macedo VO. Influência da exposição à reinfecção na evolução da doença de Chagas. Rev Patol Trop. 1976;5:33-116.

30. Dias JCP. Doença de Chagas: sucessos e desafios. Cad. Saúde Pública. 2006;22(10):2020-21.

31. Rassi AJr, Rassi A, Little WC, Xavier SS, Rassi SG, Rassi AG, et al. Development and validation of a risk score for predicting death in Chagas' heart disease. N Engl J Med. 2006;355(8):799-808.

32. Cabral DMG, Abrahão Júnior LJ, Marques CHD, Pereira BB, Pedrosa RC. Oropharingeal dysphagia in patients with chronic Chagas disease: phonoaudiological, videofluoroscopic, and manometric evaluations. Acta Fisiatr. 2015;22(1):24-29.

33. Geraix J, Ardisson LP, Marcondes-Machado J, Pereira PCM. Clinical and nutritional profile of individuals with Chagas disease. BJID. 2007;11(4):411-14.
34. Organización Mundial de la Salud. Reporte del grupo de trabajo cietifico sobre la enfermedad de Chagas [Internet]. Buenos Aires: Organización Mundial de la Salud; 2005. 104p. [Actualizado en julio de 2007, cited 2016 Jul 28]. Available in: http://apps.who.int/ iris/bitstream/10665/69724/1/TDR_SWG_09_spa.pdf

35. Bouchard C. Atividade física e obesidade. São Paulo: Manole, 2003.

36. Murano I, Barbatelli G, Parisani V, Latini C, Muzzonigro G, Castellucci $\mathrm{M}$, et al. Dead adipocytes, detected as crown-like structures, are prevalent in visceral fat depots of genetically obese mice. Journal of lipid research. 2008;49:1562-68.

37. Combs TP, Nagajyothi, Mukherjee S, Almeida CJG, Jelicks LA, Schubert W, et al. The Adipocyte as an Important Target Cell for Trypanosoma cruzi Infection. J Biol Chem. 2005;280(25):24085-94.

38. Torres, Ana Catarina Moura. Nutrição e deglutição no paciente com megaesôfago chagásico. Dissertação(Mestrado)-UniversidadeFederal da Bahia. Escola de Nutrição, 2011. Disponível em: https://repositorio. ufba.br/ri/bitstream/ri/11540/1/Disserta\%C3\%A7\%C3\%A3o Nut_\%20Ana\%20Catarina\%20\%20Torres.pdf.

39. Assumpcao D, Domene SMA, Fisberg RM, Barros MBA. Qualidade da dieta e fatores associados entre idosos: estudo de base populacional em Campinas, São Paulo, Brasil. Cad. Saúde Pública. 2014;30(8):1680-94

40. Huybrechts I, Vereecken C, Bacquer DD, Vandevijvere S, Oyen HV, Maes L, et al. Reproducibility and validity of a diet quality index for children assessed using a FFQ. Br J Nutr. 2010;104(1):135-44.

41. Nicolosi RJ, Stucchi AF, Kowala MC, Hennessy LK, Hegsted DM, Schaeffer E. Effect of dietary fat saturation and cholesterol on LDL composition and metabolism. Arteri-osclerosis. 1990;10(1):119-28

42. Margioris NA. Fatty acids and postprandial inflammation. Curr Opin Nutr Metab Care. 2009;12(2):129-37.

43. Nagajyothi F, Weiss LM, Silver DL, Desruisseaux MS, Scherer PE, Herz J, et al. Trypanosoma cruzi utilizes the host low density lipoprotein receptor in invasion. PLoS Negl Trop Dis. 2011;5(2):e-953.

44. Rivera M, Souza A, Araujo-Jorge, T., et al. (2005). Trace Elements, Innate Immune Response and Parasites. Clinical Chemistry and Laboratory Medicine, 41(8), pp. 1020-1025.

45. Maçao LB, Wilhelm Filho, Pedrosa RC, Pereira A, Backes P, Torres MA, Fröde TS. Antioxidant therapy attenuates oxidative stress in chronic cardiopathy associated with Chagas' disease. Int J Cardiol. 2007;123(1):43-9.

46. Pitz S, März W, Wellnitz B, Seelhorst U, Fahrleitner Pammer A. Association of vitamin D deficiency with heart failure and sudden cardiac death in a large cross-sectional study of patients referred for coronary angiography. J Clin Endocrinol Metab. 2008;93(10):3927-35.

47. Nève J. Selenium as a risk factor for cardiovascular diseases. J Cardiovasc Risk. 1996;3:42-47.

48. Rivera MT, Souza AP, Moreno AH, Xavier SS, Gomes JA, Rocha MO, et al. Progressive Chagas' Cardiomyopathy is associated with low selenium levels. Am J Trop Med Hyg. 2002;66(6):706-12.

49. He K, Liu K, Daviglus ML, Morris SJ, Loria CM, Van Horn L, et al. Magnesium intake and incidence of metabolic syndrome among young adults. Circulatian. 2006;113(13):1675-82.

50. Andrade SC, Previdelli AN, Marchioni DML, Fisberg RM. Avaliação da confiabilidade e validade do Índice de Qualidade da Dieta Revisado. Rev Saúde Pública. 2013;47(4):675-83.

51. Ribeiro AC, Sávio KEO, Rodrigues MLCF, Costa THM, Schmitz BAS. Validação de um questionário de freqüência de consumo alimentar para população adulta. Rev Nutr. 2006;19(5):553-62. 